\title{
Postharvest application of fungicides, antagonists and plant products for controlling storage scab and rots of apple fruits
}

\author{
K.P. SINGH ${ }^{1 *}$, AMITABH SINGH ${ }^{2}$, R.K. PRASAD ${ }^{3}$ and J. KUMAR ${ }^{1}$ \\ ${ }^{1}$ Department of Plant Pathology, College of Agriculture, G.B. Pant University of Agriculture and Technology, Pantnagar, U.S. Nagar \\ 263 145, Uttarakhand, India \\ ${ }^{2}$ Department of Agriculture, Himalayan Institute of Pharmacy and Research, Atak Farm, Rajawala, Dehradun 248 007, Uttrarakhand, \\ India \\ ${ }^{3}$ Department of Plant Pathology, College of Forestry, Hill Campus, Ranichauri, Tehri Garhwal 249 199, Uttarakhand, India
}

Received: 20 May 2017/ Accepted: 18 July 2017/ Published online: 31 August 2017

(C) Indian Phytopathological Society 2017

\begin{abstract}
Apple scab (Venturia inaequalis) is widely prevalent in all the seasons in and around Gangotri valley. Three important commercial cultivars of apple namely, 'Red Delicious', 'Royal Delicious', and 'Golden Delicious' were screened against post-harvest rot causing fungi. Fruits of the cv. Red Delicious developed more scab lesions than those of 'Red Delicious' and 'Golden Delicious'. Scab lesions gradually increased in all the fruits of Delicious cultivars stored at ambient temperature. The rate of lesion expansion was inversely related to the number of lesions on the fruit. Scabbed fruits showed pronounced shriveling as compared to healthy fruits. Other fungal pathogens associated with scab lesions were identified as Trichothecium roseum, Penicillium expansum, Glomerella cingulata, Botrytis cinerea and Monilinia spp. which were responsible for fruit decay in storage. 'Red Delicious' was highly susceptible to most of the post-harvest pathogens. Postharvest sprays of flusilazole $(0.015 \%)$ bitertanol $(0.075 \%)$ and carbandazim $(0.05 \%)$ were effective in controlling storage scab and other rotting fungi. Biocontrol agents effective against $P$. expansum and $B$. cinerea were isolated from apple leaves, and a quantitative relation between antagonists and pathogen inoculum concentration was determined. Bitertanol $(0.075 \%)$ and Penconazole $(0.05 \%)$ were highly effective as pre-harvest sprays for inhibiting scab lesions after 30,45 and 60 days of storage at room temperature. In protective spray programme, propineb $(0.4 \%)$ was highly effective for storage rot even after 60 days. Thiophanate methyl $(0.10 \%)$ was effective against development of storage scab and fruit rot. Aonla leaf extract, garlic extract, bitertanol and carbendazim completely inhibited storage scab and fruit rot up to 60 days of postharvest dip treatment. It could be inferred that antagonists, plant products and fungicides could make an excellent strategy for controlling postharvest losses of apple fruits and increasing shelf-life of apple.
\end{abstract}

Keywords: Antagonist, apple scab, fungicide, plant product, Venturia inaequalis

Central Asia has been described to be the origin for the domestic apple. North-west Himalayan states - Himachal Pradesh, Jammu-Kashmir, and Uttarakhand are the leading producers of fresh apple (Malus domestica) in India. In these states, apples are grown at altitude ranging from $1200 \mathrm{~m}$ to $3500 \mathrm{~m}$ above mean sea level. Red, Royal and Golden Delicious are among the major apple varieties, accounting for 46,21 , and $16 \%$ of the total acreage, respectively. Scab is now well established and could cause almost total crop loss during most years, if not controlled (Singh et al., 2010). Yield losses during epidemic years (1996 and 2008) could go up to $70 \%$ or even more. Over $60 \%$ of the area under sweet varieties is now engulfed by apple scab (Singh et al., 2015, 2016). Spoilage of apples is a big problem in India, aggravated by the absence of proper storage facilities and paucity of information on factors causing losses during storage. Storage of apple fruits at low temperature during off season is essential to avoid glut in the market. Susceptibility of apple fruits to post-harvest rotting

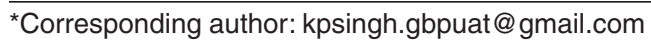

increases after prolonged storage due to physiological changes occurring in the fruits that enable pathogen development (Sharma et al., 2012). In India, losses from post-harvest diseases in fruits are reported to be between 10-40 percent (Arya, 2010; Raj and Tomar, 2013; Sharma and Kaul, 1997). Apple diseases take a heavy toll of the produce in the orchard as well as in storage. Appearance of scab lesions on apple fruit in storage degrades the quality of the produce drastically, thereby inciting huge losses to the growers. The rotting may start from any point wherever there is slightest injury to the skin. The inner tissues of the affected area of the fruit becomes light brown in colour and watery. Many post-harvest rots of pome fruit are actually initiated in the orchard. Symptoms are not always evident at harvest and may develop during storage and transportation. There are many practices that can be implemented on the farm to reduce losses from orchard-initiated post-harvest rots. Preventing disease in storage begins in the orchard: practicing orchard sanitation, properly timing fungicides, harvesting at optimum maturity and using methods to prevent bruising. Applying urea in the fall for scab 
management will also help knock back the spore of summer disease fruit rots that also infect leaves. Fungicides are the primary means of controlling postharvest diseases, including Venturia inaequalis on apple. Several workers reported that storage scab was controlled by a spray schedule. The curative fungicides controlled storage scab under conditions of low inoculum potential but at moderate and high potential, the use of protective fungicides during growing season was necessary. Post-harvest fungicidal treatment with systemic fungicides (carbendazim) was most effective against storage scab. To reduce the environmental pollution and health hazards, increasing use of chemical pesticides in management of storage pathogen is to be minimized and bioagents or botanicals may be used as they are potential substitutes. Botanicals, which are cheap and easily available, have a good potential for the management of plant pathogens (Faten and Latif, 2016; Raj and Tomar, 2013; Singh, 2006). Use of antifungal botanicals and other bio-resources have not been studied in detail for the management of storage scab of apple. Therefore, with a view to increase the shelf-life of apple and to reduce the post-harvest losses, present investigation was initiated to: (i) evaluate the pre harvest treatments with different fungicides affect on scab and fruit rot development in different apple cultivars, and (ii) evaluate the post harvest treatment with fungicides, plant products and bio-control agents affects on scab and fruit rot development in cv. Red Delicious.

\section{MATERIALS AND METHODS}

In the storage study conducted over three harvest years (2008-2010), Red Delicious apples were grown without fungicide treatments, whereas in the second standard spray schedule program of integrated protection aimed mostly at apple scab control was applied in the orchards in various apple producing areas including Dharali, Harsil and Jalla (Gangotri valley). Apples in $17 \mathrm{~kg}$ wooden boxes were harvested at the optimum maturity stage from two orchards located in Gangotri valley. Periodic data was recorded on percentage of storage scab incidence, lesions number per fruit and fruits afflicted by rots were removed.

Three apple cultivars were commercially grown in the Gangotri fruit belt of Uttarakhand. Apparently healthy fruits (free from pests and mechanical injury) of uniform size, optimum harvest maturity stage of Royal Delicious, Red Delicious, Golden Delicious and Williams apple cultivars were harvested from each cultivars in the two orchards located in Gangotri valley and wrapped in the news paper and stored in conventional wooden boxes at ambient temperature for development of storage scab. Similar studies conducted on Royal Delicious apple fruit with varied number of scab lesions were stored at ambient temperature in wooden boxes at Jhalla of Gangotri valley during each year and data were recorded on percent lesion number at 30 days interval.

Two pre-harvest sprays of fungicides (bitertanol, captan, carbendazim, thiophanate methyl) were given on Red Delicious trees at 15 days interval in Gangotri valley (Harsii). The fruits were harvested and stored in ambient conditions in wooden boxes and observed for the percent storage scab and fruit decays at 15, 30, 45, 60 , and 90 days in Gangotri fruit belt. In another orchard, penconazole $(0.05 \%)$ and flusilazole $(0.01 \%)$ were sprayed prior to harvest. The fruits were harvested and stored in the same way as above and observed for the incidence of scab and percent fruit rot after 30,60 and 90 days of storage. In a protective spray programme, nine sprays of each of the following fungicides at different phonological stages of tree were given each year on Red Delicious trees at village Jhalla of Gangotri valley. Sprays of mancozeb (Dithane M45 0.30\%), dodine (Syllit $0.075 \%$ ), propineb (Antracol 0.4\%), chlorothalonil (Kavach $0.2 \%$ ), carbendazim (Bavistin 0.05\%), penconazole (Topas 0.05\%), flusilazole (Punch 0.01\%), difenoconazole (Score $0.0375 \%$ ) and hexaconazole (Contaf $0.03 \%$ ) were given with three replications maintained in each treatment. At harvest, 30 fruits were collected from each treatment and stored at room temperature. Fruits obtained from untreated trees were similarly stored in wooden boxes. All the fruits were observed for scab infection at 0 day (no. of spots and area) and percent fruit rot after 30 and 60 days of storage.

Apparently healthy fruits of Red Delicious cultivar were procured from unsprayed orchards located in Gangotri valley area for postharvest fungicidal dip treatment for 5 minutes in different fungicides separately. Six promising fungicides, bitertanol [(B,1,1-biphenyl-4xyloxy)-1-1-(1-1-dimethylethyl)-1H-1, 2,4-triazole-1ethanol], captan $\left(\mathrm{C}_{2} \mathrm{H}_{2} \mathrm{Cl}_{2} \mathrm{NO}_{2} \mathrm{~S}\right)$, carbendazim (methyl2-benzimidazole carbamate), flusilazole $\left(\mathrm{C}_{16} \mathrm{H}_{15} \mathrm{~F}_{2} \mathrm{~N}_{3} \mathrm{Si}\right.$ ), difenoconazole $\left(\mathrm{C}_{19} \mathrm{H}_{17} \mathrm{Cl}_{2} \mathrm{~N}_{3} \mathrm{O}_{3}\right)$ and thiophanate-methyl (dimethyl-4,4-0-phenylene bis-3-thioallophanate) found effective in curative and protective trials, were further evaluated in postharvest fungicides dip treatment. Fruits kept as checks were dipped in water only. The treated fruits were dried in shade for half an hour and packed in wooden boxes. The boxes were then kept under ambient temperature for a period of 90 days. Observations on scab and rotting were recorded after 45,60 and 90 days of treatment.

Leaves of plant spp. viz., neem (Azadirachta indica), aonla (Emblica officinalis G), artimisia (Artemisia vulgaris) and bottle brush (Callistemon spp.) were initially washed, air dried and individually crushed in a warring blender using sterile water $(1: 1 \mathrm{w} / \mathrm{v})$. The extract was filtered through a double layered muslin cloth and centrifuged at $5000 \mathrm{rpm}$ for $15 \mathrm{~min}$. The clear supernatant was collected and considered as $100 \%$ stock. An isolate of Trichoderma harzianum and Gliocladium virens, from Plant Pathology laboratory, G.B.P.U.A.\&T., Hill Campus, Ranichauri, India, were used to inoculate $5-$ ! conical flasks containing $2-$ ! of potato dextrose broth. Flasks were incubated at $25 \pm 2^{\circ} \mathrm{C}$. After 15 days medium was filtered through a Millipore filter $(0.22 \mu \mathrm{m})$ and diluted to 50 percent with sterile distilled water. Similarly, four freshly prepared leaf aqueous extracts of locally available plants as mentioned above, known for their antimicrobial 
properties at 100 percent concentration were tested for their fungicidal activity on the development of storage scab, fruit rot and cumulative shriveling in apple up to 60 days. In each year, Red Delicious apple harvested from the hot spot locations of apple scab in Gangotri valley were dipped for 30 minutes in above plant extracts and antagonist and for 5 minutes in the standard protectant fungicides at recommended doses (Bitertanol, Carbandazim) in different lots of 30 fruits, normal water served as control.

Ginger rhizome extract was prepared by crushing the rhizomes in a blender and centrifuging the ground rhizomes at $5000 \mathrm{rpm}$ for 30 minutes. The supernatant was taken as 100 percent was diluted with sterile distilled water in two different concentrations (25:1, 50:1). Econeem collected from Hoffmann laboratory, Institute of Agricultural Sciences, BHU, Varanasi, was diluted with sterile distilled water in two different concentrations $(0.2$, $0.4 \%$ ). During each year, fruits collected from hot spot orchards, Gangotri valley, were given the dip treatment for 30 and 60 minutes in above plant products and 10 minutes in the standard protectant fungicides (flusilazole, carbandazim, defenoconozole) in different lots of 30 fruits per treatment. Treated fruits were dried in shade for half an hour, wrapped in news paper pieces and packed in wooden boxes. Each treatment was replicated thrice with 10 fruits in each replication. Before storage, data were taken for each graded fruit with respect of diameter, measured, the number of lesions and diameters of lesions. Scab and fruit rot incidence was recorded after 30 and 60 days of storage at room temperature.

\section{RESULTS AND DISCUSSION}

The fruit rot occurred during the normal storage life of apple cultivars susceptible to storage diseases based on the observance of samples harvested from the orchard without fungicides applications in 2008-2010
(Fig. 1). Number of rotted apples increased very rapidly towards the end of the normal storage life of the cultivars, reaching to an average $7.57 \%$ of lost fruits at that stage. However, economically significant losses caused by the occurrence of storage diseases of apples arose only during the last quarter of the storage period. Fruit samples that were harvested from the orchard integrated with plant protection measures had $3.54 \%$ of rotted fruits at the end of their storage life on average (Fig. 2). Similar observations were also seen on occurrence of storage rot on apples obtained from comparable conditions in other studies (Deel and Prange, 1993). Blazek et al. (2006) further reported that fruits of very susceptible cultivar were destroyed by rotting after 100 days storage. Kaul (1984) also found that most of the commercial apple cultivars were susceptible to rot causing fungal pathogens. Economically significant losses caused by rotting of apples were usually recorded only during the last month of their normal storage life.

In Gangotri valley, apple scab lesions appeared after 45 days of storage in all the cultivars. After 45 and 60 days of storage, Red Delicious fruits showed more scab as compared to other cultivars (Table 1). The fruits which were free from scab developed 1.0 scab lesions after 30 days of storage, 3.0 lesions after 60 days and 4.0 lesions after 90 days of storage. We also observed lesions developing in storage on a few fruits that were free of scab lesions at harvest. The new scab lesions developed more in fruits having scab lesions (1-5) at different time of storage. There was a gradual increase in the number of scab lesions on all the fruits of Delicious cultivars. Lesion number increased from 5 to $8.6,12.3$ and 16.4 after 30,45 and 60 days of storage, respectively (Table 2). At Gangotri fruit belt, there was no rotting up to 30 days in fruits with less than 10 scab lesions, however, fruits showing more than 10 lesions resulted in 19 percent rotting after 45 days of storage. Scabbed fruits showed pronounced shriveling as compared to healthy fruits.

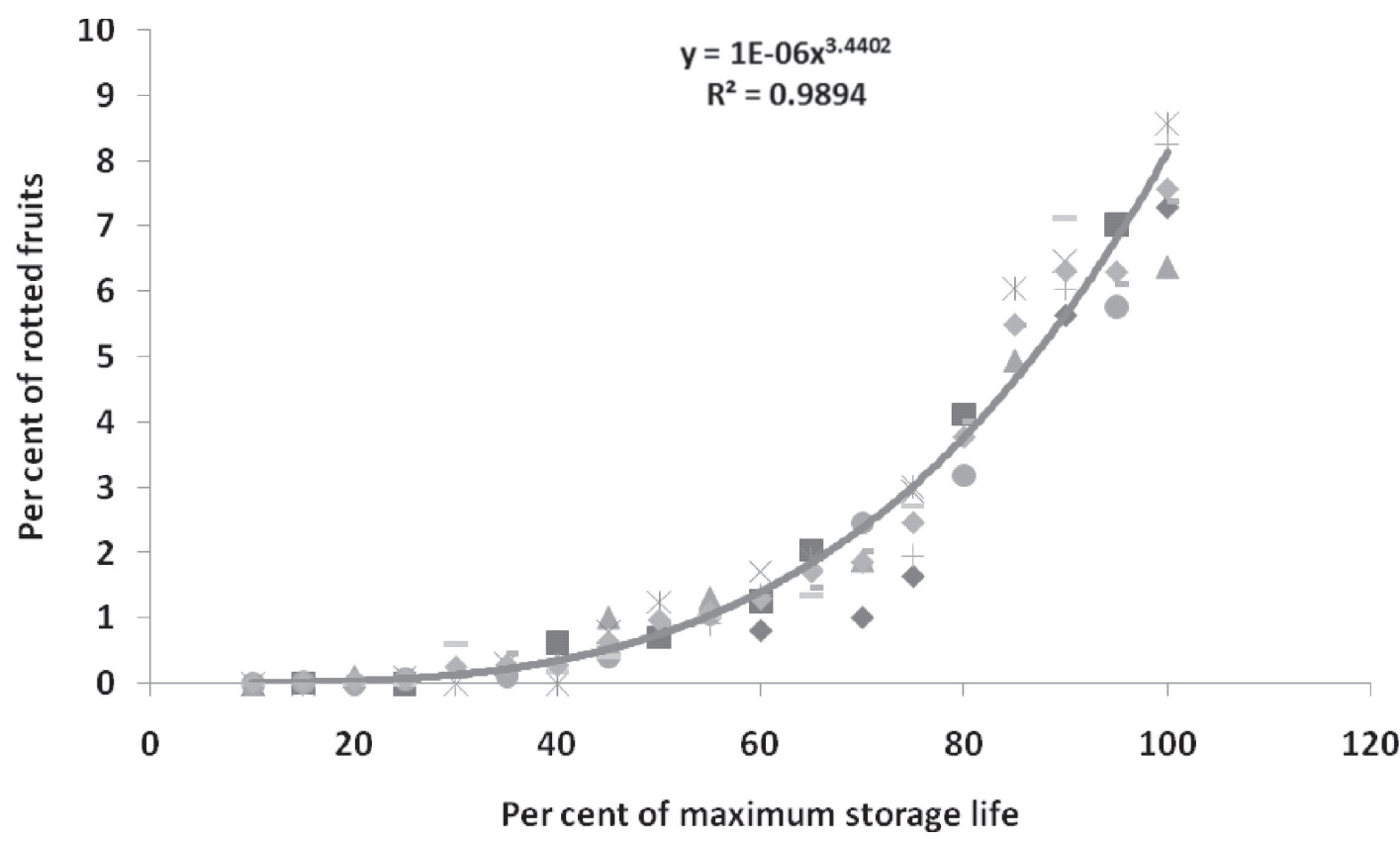

Fig. 1. Impact of storage life on the percentage of rotted fruits grown without fungicides 


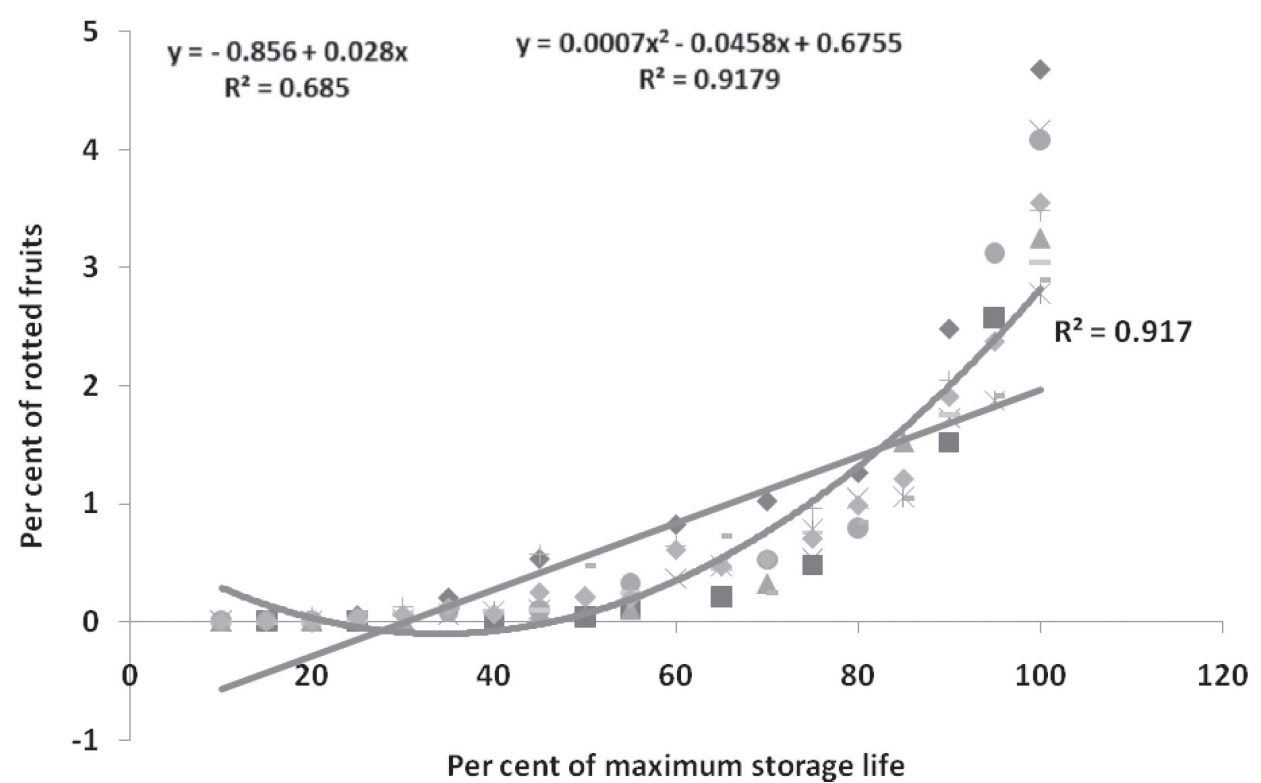

Fig. 2. Impact of storage on the percent rotting of fruits grown following application of fungicides

Table 1. Development of storage scab in commercial apple cultivars at Gangotri fruit belt

\begin{tabular}{|c|c|c|c|c|c|c|c|}
\hline \multirow[t]{2}{*}{ Cultivar } & \multicolumn{3}{|c|}{ Percent storage scab incidence (Days after) } & \multicolumn{4}{|c|}{ Average number of lesions per fruit } \\
\hline & 30 & 45 & 60 & 30 & 45 & 60 & Mean \\
\hline Royal Delicious & 0.00 & 7.13 & 13.46 & 5.40 & 60.00 & 5.80 & 5.73 \\
\hline Golden Delicious & 0.00 & 5.80 & 10.20 & 60.00 & 80.00 & 6.20 & 6.73 \\
\hline Red Delicious & 0.00 & 14.20 & 25.50 & 9.20 & 10.00 & 9.80 & 9.66 \\
\hline Williams & 0.00 & 2.60 & 8.73 & 6.50 & 6.80 & 5.70 & 6.33 \\
\hline$C D(p=0.05)$ & & 0.98 & 2.81 & & & & 1.01 \\
\hline CV & & 6.63 & 9.75 & & & & 7.13 \\
\hline
\end{tabular}

Table 2. Development of storage scab and fruit rot in storage

\begin{tabular}{|c|c|c|c|c|c|c|c|}
\hline \multirow{2}{*}{$\begin{array}{l}\text { No. of lesions } \\
\text { (at the time of storage) }\end{array}$} & \multicolumn{3}{|c|}{ Lesion number (after days) } & \multicolumn{4}{|c|}{ Average number of lesions per fruit } \\
\hline & 30 & 60 & 90 & 30 & 60 & 90 & Mean \\
\hline 0 & 0.00 & 0.33 & 0.50 & 0.10 & 0.30 & 0.4 & 0.27 \\
\hline 1 & 5.10 & 6.27 & 8.53 & 6.20 & 5.40 & 6.2 & 5.93 \\
\hline 2 & 4.40 & 6.40 & 8.73 & 6.00 & 6.40 & 6.8 & 6.40 \\
\hline 3 & 6.27 & 8.70 & 13.63 & 9.50 & 9.00 & 8.6 & 9.03 \\
\hline 4 & 7.43 & 11.1 & 15.43 & 11.40 & 11.00 & 10.8 & 11.07 \\
\hline 5 & 8.60 & 12.03 & 16.00 & 12.00 & 12.40 & 12.50 & 12.30 \\
\hline$C D(p=0.05)$ & 1.11 & 0.89 & 1.05 & & & & 0.63 \\
\hline CV & 11.87 & 6.73 & 5.65 & & & & 4.75 \\
\hline
\end{tabular}

Other pathogens found associated with scab lesion were identified as Trichothecium roseum, Monilinia spp., Glomerella cingulata, Alternaria alternate, Penicillium spp., Aspergillus spp., and Botrytis cinerea (Table 3). Singh and Sumbali (2004) observed that apple cultivars were highly susceptible to $P$. expansum, $R$. stolonifer, $A$. niger, L. theobromae and T. pseudokoningi producing maximum rot. They reported that the cultivar Red Delicious was highly susceptible to most of the postharvest pathogens. Pink mould rot (Trichothecium roseum) of apple is also associated with scab lesions that penetrate the healthy fruits in storage. The symptoms appear as small brown spots, later increase in size, with light centre and brown margins.

Among the fungicides, bitertanol $(0.075 \%)$ was found highly effective in inhibiting scab lesions development up 100, 87.02 and 76.42 percent after 30, 45 and 60 days of storage at room temperature, respectively (Table 4). However, carbendazim was found highly effective to check the fruit rotting up to 85.1, 74.05, 62.6 percent after 30,45 and 60 days of storage. Pre-harvest sprays 
Table 3. Development of Venturia inaequalis in storage fruit

\begin{tabular}{|c|c|c|c|c|c|c|}
\hline \multirow[t]{2}{*}{ Days } & \multicolumn{4}{|c|}{ Fruit rotting with scab lesions } & \multicolumn{2}{|c|}{ Percent cumulative shriveling } \\
\hline & 0 & $1-5 \%$ & $5-10 \%$ & $>10 \%$ & Healthy & Scabbed \\
\hline 30 & 0.00 & 0.00 & 0.00 & 9.00 & 0.00 & 19.00 \\
\hline 45 & 0.00 & 0.00 & 8.33 & 19.33 & 9.33 & 45.00 \\
\hline 60 & 5.67 & 10.00 & 21.33 & 48.00 & 19.00 & 78.00 \\
\hline$C D(p=0.05)$ & 0.66 & 1.15 & 2.48 & 2.89 & 3.11 & 4.31 \\
\hline $\mathrm{CV}$ & 17.64 & 17.32 & 12.61 & 5.71 & 16.55 & 4.56 \\
\hline
\end{tabular}

Table 4. Efficacy of pre-harvest fungicidal sprays on storage scab and fruit rot in apple

\begin{tabular}{|c|c|c|c|c|c|c|}
\hline \multirow[t]{2}{*}{ Fungicides } & \multirow{2}{*}{$\begin{array}{c}\text { Conc. } \\
(\%)\end{array}$} & \multicolumn{5}{|c|}{ Percent scabbed fruits (days after) } \\
\hline & & 15 & 30 & 45 & 60 & 75 \\
\hline Bitertanol & 0.075 & 0.00 & 0.00 & 2.03 & 2.53 & 5.27 \\
\hline Captan & 0.20 & 0.00 & 0.87 & 5.90 & 10.43 & 19.37 \\
\hline Carbendazim & 0.05 & 0.00 & 1.33 & 4.43 & 8.80 & 15.17 \\
\hline Thiophanate methyl & 0.05 & 0.00 & 1.00 & 4.10 & 8.73 & 16.93 \\
\hline Control & & 0.90 & 7.90 & 16.83 & 25.76 & 34.27 \\
\hline$C D(p=0.05)$ & & 0.37 & 0.53 & 2.03 & 2.47 & 2.00 \\
\hline CV & & 13.35 & 13.31 & 16.84 & 12.10 & 6.05 \\
\hline
\end{tabular}

Table 5. Effect of pre-harvest fungicides sprays on development of storage scab and fruit rot of apple

\begin{tabular}{|c|c|c|c|c|c|c|c|}
\hline \multirow[t]{2}{*}{ Fungicides } & \multirow{2}{*}{$\begin{array}{c}\text { Conc. } \\
(\%)\end{array}$} & \multicolumn{3}{|c|}{ Percent scab incidence (days after) } & \multicolumn{3}{|c|}{ Percent fruit rot (days after) } \\
\hline & & 30 & 60 & 90 & 30 & 60 & 90 \\
\hline Penconazole & 0.05 & 1.30 & 1.89 & 2.41 & 6.34 & 25.33 & 40.10 \\
\hline Flusilazole & 0.01 & 1.66 & 2.04 & 2.66 & 3.45 & 20.01 & 26.61 \\
\hline Control & & 8.01 & 15.03 & 19.16 & 9.67 & 27.08 & 29.91 \\
\hline$C D(p=0.05)$ & & 0.72 & 0.72 & 0.71 & 2.29 & 1.00 & 1.22 \\
\hline CV & & 9.89 & 5.68 & 14.21 & 7.73 & 2.54 & 3.39 \\
\hline
\end{tabular}

of carbendazim and captan recorded complete control of post harvest fruit decay for upto 60 days as reported (Sharma and Kaul, 1997). Both the EBI fungicides were effective in controlling storage scab but these were not effective in controlling storage rots. Penconazole (0.05\%) inhibited scab incidence up to an extent of 86.38 percent after 90 days of storage at room temperature (Table 5). In protective spray programme, propineb $(0.4 \%)$ remained free from storage rot even after 60 days. Other effective treatments were carbendazim $(0.05 \%)$, mancozeb $(0.3 \%)$, flusilazole $(0.01 \%)$ and penconazole $(0.05 \%)$ (Table 6$)$. Schwabe $(1980,1982)$ found that treatments with curative fungicides long after infection but before storage did not adequately control storage scab and suggested that if a high probability of infection existed late in the season, the fruits should not be put into long-term storage.

All the fungicides gave good control of storage scab. Thiophanate methyl $(0.10 \%)$ was effective in checking storage scab up to 90 days in comparison to other fungicides followed by difenoconazole $(0.015 \%)$. However, difenoconazole and carbendazim were effective against fruit rot pathogen. Both these fungicides completely checked fruit rotting up to 60 days (Table 7). Several new fungicides that are being developed or that have recently been registered showed promise to protect produce from a number of diseases after harvest. The new class of strobilurin fungicides that provide postharvest control of several diseases in fruits and vegetables, one especially effective against fruit scab on apples, and should reduce the presence of pinpoint scab in storage.

Aonla leaf extract along with bitertanol and carbendazim completely inhibited the storage scab and fruit rot up to 60 days except bitertanol which was effective against rotting up to 30 days only. Culture filtrates of Gliocladium sp. and Trichoderma sp. were next best effective up to 30 days against storage scab and up to 60 days against fruit rot pathogens. The effect of culture filtrate of Trichoderma harzianum on powdery mildew of pea has been reported by Singh et al. (1993). All other treatments were less effective against storage scab but showed their effectiveness against rotting pathogens. None of the treatments except carbendazim was found to check shriveling of the stored produce (Table 8). Garlic extract was least effective in checking storage rot to any 
Table 6. Efficacy of pre-harvest fungicidal sprays on storage scab on fruit rot in Red Delicious apple

\begin{tabular}{|c|c|c|c|c|c|c|}
\hline \multirow[t]{2}{*}{ Fungicides } & \multirow{2}{*}{$\begin{array}{c}\text { Conc. } \\
(\%)\end{array}$} & \multicolumn{2}{|c|}{ Infection at 0 day } & \multicolumn{2}{|c|}{ Percent fruit rot (after days) } & \multirow[t]{2}{*}{ Marginal mean } \\
\hline & & No. of spots & Area & 30 & 60 & \\
\hline Mancozeb & 0.30 & 3.87 & 1.23 & 0.00 & 7.83 & 3.61 \\
\hline Dodine & 0.075 & 2.70 & 0.97 & 0.00 & 21.52 & 10.77 \\
\hline Propineb & 0.40 & 1.03 & 0.53 & 0.00 & 0.00 & 0.00 \\
\hline Chlorothalonil & 0.20 & 2.57 & 1.03 & 5.38 & 32.56 & 19.20 \\
\hline Carbendazim & 0.05 & 0.63 & 0.50 & 5.68 & 10.49 & 7.62 \\
\hline Penconazole & 0.05 & 5.31 & 1.62 & 7.56 & 17.81 & 12.27 \\
\hline Flusilazole & 0.01 & 9.33 & 2.27 & 3.35 & 13.47 & 8.45 \\
\hline Difenoconazole & 0.0375 & 1.93 & 0.57 & 16.69 & 23.24 & 20.67 \\
\hline Hexaconazole & 0.03 & 2.80 & 1.70 & 13.59 & 27.47 & 20.76 \\
\hline Control & & 38.13 & 11.77 & 22.45 & 45.25 & 35.29 \\
\hline$C D(p=0.05)$ & & 1.91 & 1.17 & 1.73 & 3.27 & 3.03 \\
\hline $\mathrm{CV}$ & & 16.43 & 30.98 & 13.64 & 9.62 & 12.86 \\
\hline
\end{tabular}

Table 7. Effect of fungicidal dip treatment on the development of storage scab and fruit rot

\begin{tabular}{|c|c|c|c|c|c|c|c|}
\hline \multirow[t]{2}{*}{ Fungicides } & \multirow{2}{*}{$\begin{array}{c}\text { Conc. } \\
(\%)\end{array}$} & \multicolumn{3}{|c|}{ Percent scab incidence after days } & \multicolumn{3}{|c|}{ Percent fruit rot after days } \\
\hline & & 45 & 60 & 90 & 45 & 60 & 90 \\
\hline Bitertanol & 0.075 & 3.58 & 9.00 & 11.21 & 3.78 & 10.54 & 18.39 \\
\hline Captan & 0.20 & 7.58 & 9.75 & 15.01 & 4.77 & 10.52 & 15.81 \\
\hline Carbendazim & 0.05 & 5.62 & 10.17 & 12.94 & 0.00 & 0.00 & 3.45 \\
\hline Flusilazole & 0.02 & 3.75 & 9.72 & 12.26 & 1.94 & 6.68 & 10.49 \\
\hline Difenoconazole & 0.015 & 2.17 & 6.40 & 7.36 & 0.00 & 0.00 & 3.44 \\
\hline Thiophanate methyl & 0.10 & 0.93 & 1.46 & 1.96 & 2.61 & 10.77 & 13.88 \\
\hline Control & & 8.75 & 14.60 & 27.48 & 9.70 & 27.25 & 30.78 \\
\hline$C D(p=0.05)$ & & 1.15 & 1.05 & 1.51 & 1.09 & 2.22 & 1.94 \\
\hline $\mathrm{CV}$ & & 14.24 & 6.92 & 6.84 & 19.27 & 13.53 & 8.09 \\
\hline
\end{tabular}

Table 8. Effect of different plant extract, bioagents and fungicides on storage disease of apple

\begin{tabular}{|c|c|c|c|c|c|c|c|}
\hline \multirow[t]{2}{*}{ Treatments } & \multirow[t]{2}{*}{$\begin{array}{l}\text { Conc. } \\
(\%)\end{array}$} & \multicolumn{2}{|c|}{$\begin{array}{l}\text { Percent storage scab } \\
\text { (after days) }\end{array}$} & \multicolumn{2}{|c|}{$\begin{array}{l}\text { Percent cumulative rot } \\
\text { (after days) }\end{array}$} & \multicolumn{2}{|c|}{$\begin{array}{l}\text { Percent cumulative shriveling } \\
\text { (after days) }\end{array}$} \\
\hline & & 30 & 60 & 30 & 60 & 30 & 60 \\
\hline Neem leaf extract & & 11.28 & 25.03 & 0.00 & 12.64 & 59.33 & 98.36 \\
\hline Aonla leaf extract & & 0.00 & 0.94 & 0.00 & 3.58 & 69.25 & 91.11 \\
\hline Artimisia leaf extract & & 12.60 & 15.61 & 0.00 & 2.28 & 62.28 & 96.81 \\
\hline Bottle brush leaf extract & & 13.59 & 25.51 & 0.00 & 5.28 & 75.39 & 79.11 \\
\hline Gliocladium & 50 & 1.18 & 4.58 & 0.00 & 3.91 & 79.71 & 94.20 \\
\hline Trichoderma & 50 & 2.82 & 4.55 & 0.00 & 3.89 & 78.65 & 95.64 \\
\hline Bitertanol & 0.075 & 0.00 & 0.00 & 8.02 & 11.19 & 61.05 & 78.64 \\
\hline Carbendazim & 0.05 & 0.00 & 0.00 & 0.00 & 0.00 & 21.99 & 46.28 \\
\hline Control (water) & & 23.11 & 36.18 & 12.05 & 23.95 & 88.22 & 100.00 \\
\hline$C D(p=0.05)$ & & 1.95 & 2.83 & 1.12 & 2.67 & 3.41 & 3.65 \\
\hline CV & & 15.89 & 13.22 & 29.3 & 21.05 & 3.00 & 2.45 \\
\hline
\end{tabular}

extent, though Econeem at 0.2 and 0.4 percent proved quite effective. Maximum protection up to 2 months of storage was seen by flusilazole $(0.01 \%)$, carbendazim $(0.025 \%)$ and difenoconazole $(0.015 \%)$ (Table 9$)$. Ajoene, a compound derived from garlic (Allium sativum L.), inhibited spore germination of some fungi, namely, Alternaria solani, Alternaria tenuissima, Alternaria triticina, Alternaria sp., Colletotrichum sp., Curvularia sp., Fusarium lini, Fusarium oxysporum, Fusarium semitectum, and Fusarium udum, which cause serious diseases in some important crop plants in India (Singh et al., 1990). The active principle isolated from ginger by Singh et al. (1983) has been found fungitoxic against spore germination of a number of fungi. To reduce the 
Table 9. Effect of fungicidal dip treatments on the development of storage scab and fruit rot in Red Delicious apple

\begin{tabular}{|c|c|c|c|c|c|c|}
\hline \multirow[t]{2}{*}{ Treatment } & \multirow{2}{*}{$\begin{array}{l}\text { Conc. } \\
(\%)\end{array}$} & \multirow{2}{*}{$\begin{array}{l}\text { Dipping time } \\
\text { (min.) }\end{array}$} & \multicolumn{2}{|c|}{ Infection at 0 day } & \multicolumn{2}{|c|}{ Percent fruit rot after days } \\
\hline & & & No. of spots & $\overline{\text { Area }}$ & 30 & 60 \\
\hline \multirow[t]{4}{*}{ Econeem } & 0.20 & 60 & 19.20 & 08.60 & 26.14 & 38.45 \\
\hline & 0.20 & 30 & 17.50 & 04.20 & 29.72 & 60.36 \\
\hline & 0.40 & 60 & 16.50 & 07.30 & 16.10 & 54.65 \\
\hline & 0.40 & 30 & 19.10 & 06.50 & 19.16 & 32.38 \\
\hline \multirow[t]{2}{*}{ Garlic extract (50:1) } & 0.20 & 60 & 23.90 & 08.90 & 40.50 & 76.72 \\
\hline & 0.20 & 30 & 26.60 & 09.90 & 42.75 & 44.44 \\
\hline \multirow[t]{2}{*}{ Garlic extract (25:1) } & 0.40 & 60 & 32.20 & 11.80 & 38.46 & 72.70 \\
\hline & 0.40 & 30 & 32.90 & 13.80 & 46.74 & 100.00 \\
\hline Flusilazole & 0.01 & 10 & 22.80 & 08.80 & 10.14 & 20.42 \\
\hline Carbendazim & 0.025 & 10 & 20.10 & 06.60 & 08.46 & 20.16 \\
\hline Difenoconazole & 0.015 & 10 & 27.90 & 10.70 & 20.26 & 30.25 \\
\hline Control & & & 32.90 & 13.90 & 48.74 & 100.00 \\
\hline
\end{tabular}

environmental pollution and health hazards, increasing use of chemical pesticides in management of storage pathogen is to be minimized and bioagents or plant products may be used as they are potential substitutes.

\section{ACKNOWLEDGEMENT}

The authors are thankful to ICAR, New Delhi for providing financial support under project entitled "Investigation on development of bio-control measures for the management of saprophytic stage of apple scab pathogen Venturia inaequalis in Uttaranchal Himalayas". Authors are also thankful to the Dean, College of Forestry \& Hill Agriculture, GBPUAT, Ranichauri for providing necessary facilities to carry out the research work

\section{REFERENCES}

Arya A (2010). Recent advances in the management of fungal pathogens of fruit crops, In: Management of fungal plant pathogen (Arya A and Perello AE Eds.), 403 pp. CABI.

Blazek J, Kloutvorova J and Krelinova J (2006). Incidence of storage diseases on apples of selected cultivars and advanced selections grown with and without fungicide treatments. Hort. Sci. 33: 87-94.

Deell JR and Prange RK (1993). Postharvest physiological disorders, diseases and mineral concentrations of organically and conventionally grown Mclntosh and Cortland apple. Can. J. Plant Sci. 73: 223-230.

Faten M and Abd-El-Latif (2016). Postharvest application of some essential oils for controlling gray and blue moulds of apple fruits. Plant Pathol. J. 15: 5-10.

Kaul JL (1984). Fruit susceptibility in relation to nutritional status of different apple cultivars to fungal rots. Indian Phytopath. 37: 449-452.

Raj $\mathrm{H}$ and Tomar M (2013). Use of aqueous and cow urine based plant extract against post-harvest diseases of apple. J. Mycol. Plant Pathol. 43: 246-249

Schwabe WFS (1980). Prevention of storage scab of apples. Phytophylactica 12: 209-211
Schwabe WFS (1982). Wetting and temperature requirements for infection of mature apple by Venturia inaequalis in South Africa. Ann. Appl. Biol. 100: 415-423

Sharma JN and Kaul JL (1997). Studies on the development of storage scab in apple and its management. Indian Phytopath. 50: 396-401

Sharma RN, Maharshi RP and Gaur RB (2012). Biocontrol of post-harvest green mould rot (Penicillium digitatum) of kinnow fruits using microbial antagonists. Indian Phytopath. 65: $276-281$

Singh KP (2006). Investigation on development of bio-control measures for the management of saprophytic stage of apple scab pathogen Venturia inaequalis in Uttaranchal Himalayas. ICAR, Report New Delhi, 53pp.

Singh UP, Mishra GD and Singh KP (1993). Control of powdery mildew (Erysiphe pisi) of pea (Pisum sativum) by the application of culture filtrate of Trichoderma harzianum. Phytophylactica 25: 269-270.

Singh KP, Kumar J and Kumar B (2010). GBPUAT and Apple Disease Research in the Gangotri Valley Region of India. In: Microbial Diversity and Plant Disease Management, Singh, K.P. and D.K. Shahi (Eds.). GmbH and Co., Germany, pp: 276-301.

Singh KP, Kumar J, Singh A, Prasad RK, Singh RP and Prasad D (2015). Predicting Potential Ascospore Dose of Venturia inaequalis (Cks) Wint in Farmers Apple Orchards in Central Himalayas of India. Plant Pathol. J. 14: 189-195.

Singh KP, Kumar J, Singh A, Prasad RK, Singh RP and Prasad D (2016). Maturation, ascospore discharge pattern and relevance of Mills criteria for predicting apple scab infection period in India. Plant Pathol. J. 15: 108-123.

Singh UP, Pandey VN, Wagner KG and Singh KP (1990). Antifungal activity of ajoene, a constituent of garlic (Allium Sativum). Can. J. Bot. 68: 1354-1356.

Singh V, Tripathi RD, Tripathi NN and Dixit SN (1983). Isolation and properties of fungitoxic principle for Zingiber officinale. Indian J. Plant Path. 1: 89-96

Singh YP and Sumbali G (2004). Performance of apple and pear cultivars to post-harvest fruit rot fungi. J. Mycol. PI. Pathol. 34: 914-916. 